\title{
Device Returned To Reprocessor Date
}

National Cancer Institute

\section{Source}

National Cancer Institute. Device Returned To Reprocessor Date. NCI Thesaurus. Code C93807.

The date (and time) on which the device was returned to the manufacturer or reprocessor. 